DOI: https://doi.org/10.30749/2594-8261.v3n2p199-201

\title{
PONTES DE MIRANDA: UM BRASILEIRO
}

Da terra natal, um caráter moldou-se pela

palavra e pela escrita, contrariando a tradição

da espada dos marechais presidentes,

uma vez que a República exigia muito mais

do que as alagoas...

A austeridade ascendente,

correndo no sangue, rendia-se

àquele que resistira às armadilhas

da natureza, ao lhe dar o mundo

como que num rompante,

aos seis meses de gestação...

Eis o sinal de uma celeridade

convertida em signo, mais adiante.

A precocidade fez-se então a marca

de uma vida, ao tempo em que

a inteligência dimensionava-se

no universo de um lugar,

sob a têmpera do novo,

sempre a descobrir.

Não faltaram jogos infantis, nem o pé

no mangue, naquela caça ao molusco

Sururu, iguaria de grande frequência

nas fartas mesas nordestinas,

do mesmo modo que não faltaram 
as corridas por entre o canavial do engenho avoengo.

O contato com as coisas da terra, da culinária às cantigas de um folclore mítico, multiétnico, povoado de elementos mágicos das ocas ao redor, assim como dos quilombos das serras, desenhavam o cenário em que se embalavam muitos dos seus sonhos.

Do Convento dos Franciscanos, ao Liceu, chegou aos dezesseis anos à Recife, indo ao encontro de Thémis, deusa que lhe regeu o caminho vida afora, ou por trama hereditária, ou, certamente, por mitológico capricho...

Os deuses sempre conspiram!

Logo o Rio de Janeiro, Distrito Federal, fez-se palco de uma múltipla trajetória, da advocacia à magistratura, do jornalismo assíduo, em coluna do Jornal do Comércio, aos círculos literários, sociedades de amigos, na maioria escritores e advogados, um universo onde a interlocução transitava dos jornais e livrarias às tribunas, e destas, às ruas. 
A família e o meio social

gradativamente passam a gravitar em torno

de um lugar, Ipanema, onde a

residência convertera-se, conforme

Albion, em um projeto civilizatório,

do "eterno" embaixador,

do mesmo modo honorário professor,

assim como da confluência da toga e

da obra jurídica e poética,

com o seu publicismo

e afetos.

Da "Albion-residência" ao mundo,

do mundo sempre à Maceió e ao

Distrito Federal, um circuito refazendo-se continuamente,

fundado na brasilidade nativa,

ostentada em verde-amarelo,

orgulho de uma vida,

vivida plenamente por

87 anos, em honra da

Pátria!

Celina Alves Brum

Rio de Janeiro, 26 de fevereiro de 2019. 